\title{
Construction and Evaluation of High-Quality Development Index System for Private Cultural Service Enterprises
}

\author{
$\mathrm{Ji} \mathrm{Zhu}^{1, *}$ \\ ${ }^{1}$ School of Finance, Jiangxi Normal University, Nanchang, Jiangxi 330022, China \\ *Corresponding author. Email: 780201105@qq.com
}

\begin{abstract}
The high-quality development of private cultural enterprises is an important engine to improve the modern cultural industry system and market system. This paper defines the connotation of the high-quality development of private cultural enterprises theoretically, and holds that private cultural enterprises need to take an efficient, coordinated and sustainable path to achieve high-quality development. Combining with the management practice of private cultural enterprises, this paper constructs an evaluation index system for the high-quality development of private cultural enterprises is constructed from three dimensions of development, efficiency and sustainability. Based on the data of 40 A-share listed private cultural service enterprises, this paper uses the entropy method-TOPSIS evaluation model to measure the comprehensive index level of the high-quality development of private cultural companies from 2013 to 2019. The analysis results show that the level of high-quality development of private cultural enterprises is not high. At present, the main factors affecting the development of private cultural enterprises are low social benefits, low operating efficiency and poor operation capacity. Weak technological competitiveness leads to lack of motivation for the company's subsequent growth, and at the same time, the company pays insufficient attentions to environmental friendliness.
\end{abstract}

Keywords: Private cultural enterprise, High-quality development, Evaluation system, Degree.

\section{INTRODUCTION}

The revenue growth point of China's cultural industry continues to tilt toward the service industry, The number and scale of cultural enterprises have grown rapidly. However, there are still some problems in cultural enterprises, such as insufficient investment in talents, technology and capital, and weak innovation capacity. Among them private cultural enterprises as an important subject of the development of China's cultural industry, to achieve high-quality development is an important part of expanding the supply of high-quality cultural products. However, due to the limitations of their own capital scale and development resources (Dai Xinling, 2020), private cultural enterprises face increasing pressure in the transition period of cultural industry, and they face more complex difficulties and challenges in achieving high-quality development. How do private cultural enterprises achieve high quality development? The high-quality development of China's private cultural enterprises has special mission and development connotation. It is a cultural form first and a modern economic form second. Compared with state-owned cultural enterprises, private cultural enterprises are less influenced by government support and policies and systems (Xie Di and Li Ziqi, 2018) facing stronger resource constraints (Du Xianghong and Zhou Yongmei, 2020), Operation is highly autonomous and profit-driven, Only by dealing with the contradiction between economic value and social value can we achieve high-quality development.

On the basis of existing literature, based on the connotation of the high-quality development of private cultural enterprises, this paper constructs an evaluation index system suitable for the high-quality development of private cultural enterprises. Based on the data of 40 listed private cultural enterprises from 2013 to 2019, this paper evaluate the development quality level of private cultural enterprises and the coordinated development level of private cultural enterprises, analyzing the main problems existing in the 
development of private cultural enterprises in China. And put forward targeted suggestions to promote the coordinated development of private cultural enterprises to provide new ideas.

\section{CONSTRUCTION AND EVALUATION METHOD OF INDEX SYSTEM.}

\subsection{Construction}

\section{of Index System and Source and Processing of Data.}

While China's economy has achieved tremendous growth, the problem of imbalance, uncoordination and unsustainable has become prominent. High-quality economic development is relative to the rapid economic growth put forward, focusing on solving the above problems, in order to achieve efficient, coordinated and sustainable development. For private cultural enterprises, the connotation of high-quality development is that private cultural enterprises take an efficient, coordinated and sustainable development road. Starting from the theoretical level of the definition of the connotation of high-quality development of private cultural enterprises and the level of the actual economic efficiency of private cultural enterprises, this paper constructs three aspects: development, efficiency and sustainability. The high quality development evaluation system of private cultural enterprises, including 8 secondary indicators such as profitability, social benefit and operation efficiency, and 17 specific indicators including $\mathrm{R} \& \mathrm{D}$ investment intensity and environmental data disclosure, is shown in Table 1 (The weights of indicators are in parentheses). The data are mainly from CSMAR database. The annual reports of private cultural listed companies from 2013 to 2019 are taken as samples to extract and sort out the data such as annual reports and annotated information of private cultural listed companies, and evaluate the development quality level of Private cultural enterprises in China from 2013 to 2019 .

Table 1. High quality development index system of private cultural enterprises

\begin{tabular}{|c|c|c|c|}
\hline First-level indicators & Second-level indicators & Three-level indicators & $\begin{array}{l}\text { Indicator } \\
\text { attributes }\end{array}$ \\
\hline \multirow{7}{*}{ Development(0.0453) } & \multirow{3}{*}{ Profitability(0.0026) } & Net interest rates $(0.0010)$ & Positive \\
\hline & & Operating profit ratio(0.0013) & Positive \\
\hline & & Return on equity(0.0003) & Positive \\
\hline & \multirow{4}{*}{ Social benefits(0.0427) } & Shareholders' liability(0.0042) & Positive \\
\hline & & Employees responsibility $(0.0305)$ & Positive \\
\hline & & social responsibility(0.0026) & Positive \\
\hline & & Rating score $(0.0054)$ & Positive \\
\hline \multirow{4}{*}{ Efficiency(0.0507) } & \multirow{2}{*}{$\begin{array}{c}\text { Operation } \\
\text { efficiency }(0.0296)\end{array}$} & Labor productivity(0.0285) & Positive \\
\hline & & Efficiency of capital output(0.0010) & Positive \\
\hline & $\begin{array}{c}\text { Economic } \\
\text { efficiency }(0.0006)\end{array}$ & Operating expense ratio(0.0006) & Reverse \\
\hline & $\begin{array}{c}\text { Operation } \\
\text { capability }(0.0206) \\
\end{array}$ & Total asset turnover(0.0206) & Positive \\
\hline \multirow{6}{*}{ Sustainability(0.9040) } & \multirow{4}{*}{$\begin{array}{c}\text { Technological } \\
\text { competitiveness }(0.5794)\end{array}$} & R\&D investment intensity $(0.0741)$ & Positive \\
\hline & & $\begin{array}{ccc}\text { Proportion } & \text { of } & R \& D \\
\text { personnel }(0.0567) & & \\
\end{array}$ & Positive \\
\hline & & $\begin{array}{l}\text { Number of invention patents } \\
\text { granted(0.2309) }\end{array}$ & Positive \\
\hline & & $\begin{array}{l}\text { Number of invention patent } \\
\text { applications }(0.2177)\end{array}$ & Positive \\
\hline & $\begin{array}{r}\text { Enterprise } \\
\text { growth }(0.2077) \\
\end{array}$ & Growth rate of assets $(0.2077)$ & Positive \\
\hline & $\begin{array}{l}\text { Environment } \\
\text { friendly }(0.1169)\end{array}$ & $\begin{array}{l}\text { Environmental } \\
\text { disclosure(0.1169) }\end{array}$ & Positive \\
\hline
\end{tabular}




\subsection{Evaluation method}

Through entropy weight-TOPSIS evaluation model, measure the high quality development level of private cultural enterprises from 2013 to 2019. The specific steps are as follows:

Data pre-processing: calculate the value of each indicator according to the indicator meaning and associated data, do dimensionless processing for each indicator, and do same trend processing for the indicators with reverse attributes, using the following methods:

If $X_{j}$ is a positive indicator

$$
X_{i j}=\frac{X_{i j}-\min \left\{X_{1 j}, \cdots X_{n j}\right\}}{\max \left\{X_{1 j}, \cdots X_{n j}\right\}-\min \left\{X_{1 j}, \cdots X_{n j}\right\}}
$$

If $X_{j}$ is a reverse indicator

$$
\frac{\max \left\{\mathrm{X}_{1 \mathrm{j}}, \cdots \mathrm{X}_{\mathrm{nj}}\right\}-\mathrm{X}_{\mathrm{ij}}}{\max \left\{\mathrm{X}_{1 \mathrm{j}}, \cdots \mathrm{X}_{\mathrm{nj}}\right\}-\min \left\{\mathrm{X}_{1 \mathrm{j}}, \cdots \mathrm{X}_{\mathrm{nj}}\right\}}
$$

Where, $X_{i j}$ represents the $j$ evaluation of the $i$ th enterprise.

The index weight is determined according to the information entropy. According to the definition of entropy, the information entropy calculation formula of $\mathrm{j}$ evaluation indicators of the ith enterprise is established as follows:

$$
-\frac{1}{\ln n} \sum_{i=1}^{n}\left(\frac{x_{i j}}{\sum_{i=1}^{n} x_{i j}} \ln \frac{x_{i j}}{\sum_{i=1}^{n} x_{i j}}\right)
$$

Based on the entropy value $\mathrm{Ej}$, the weight $\mathrm{W}_{\mathrm{j}}$ of item $\mathrm{j}$ of high quality development of private enterprises is calculated:

$$
\begin{aligned}
& \mathrm{W}_{\mathrm{j}}=\left(1-\mathrm{E}_{\mathrm{j}}\right) / \sum_{\mathrm{j}=1}^{\mathrm{m}}(1- \\
& \left.\mathrm{E}_{\mathrm{j}}\right)
\end{aligned}
$$

The index weights obtained are shown in Table 1.

On the basis of determining the evaluation weight of each index, TOPSIS evaluation model is used for further evaluation.

Multiply each measure index $X_{i j}$ by the corresponding weights to obtain the weighted normalized matrix $A_{i j}$ :

$$
A_{i j}=X_{i j} \times W_{j}
$$

According to the weighted matrix $A_{i j}$, the optimal scheme $\mathrm{S}^{+}$and the worst scheme $\mathrm{S}^{-}$are determined

$$
\begin{aligned}
& \left(\operatorname{maxa}_{\mathrm{i} 1}, \operatorname{maxa}_{\mathrm{i} 2}, \cdots, \operatorname{maxa}_{\mathrm{in}}\right) \\
& \quad\left(\operatorname{mina}_{\mathrm{i} 1}, \operatorname{mina}_{\mathrm{i} 2}, \cdots, \operatorname{mina}_{\mathrm{in}}\right)
\end{aligned}
$$

Calculate $\mathrm{t}$ the distance between the best solution and the worst solution, $\mathrm{D}^{+}$and $\mathrm{D}^{-}$.

$$
D^{+}=\left(\sum_{j=1}^{n}\left(s_{i j}-s_{j}^{+}\right)^{2}\right)^{1 / 2}
$$

$$
\mathrm{D}^{-}=\left(\sum _ { \mathrm { j } = 1 } ^ { \mathrm { n } } \left(\mathrm{s}_{\mathrm{ij}}-\right.\right.
$$

$$
\left.\left.s_{j}^{-}\right)^{2}\right)^{1 / 2}
$$

The relative proximity $\mathrm{C}_{\mathrm{i}}$ between each measure scheme and the ideal scheme is calculated.

$\frac{D_{i}^{-}}{D_{i}^{-}+D_{i}^{+}}$

$$
\mathrm{C}_{\mathrm{i}}=
$$

\section{THE EMPIRICAL ANALYSIS}

According to information entropy weight determination method and TOPSIS evaluation method, with 40 private cultural enterprises as research samples, STATA software is used to measure the comprehensive level of high-quality development of private cultural enterprises and the three sub-indicators of development, efficiency and sustainability. The evaluation results are as follows.

\subsection{Evaluation results of sub-indexes of private cultural enterprises}

The weight of the sustainability index is 0.9040 , indicating that there is a large difference in the value of the sub-index to measure the sustainability index among different private cultural enterprises, which plays an important role in measuring the high-quality development of private cultural enterprises. The weight proportion of development and efficiency index is small and the value is similar, respectively 0.0453 and 0.0507 , which also has a certain influence on the high-quality development of private cultural enterprises.

\subsubsection{Evaluation index of development}

The weight coefficient of development index is 0.0453 , which accounts for a relatively low proportion in the comprehensive index evaluation system. From 2013 to 2019, the average closeness degree of the development index of private cultural enterprises was 0.2044 . The weight of profitability is 0.0026 , and the weight of social benefit is 0.0427 , so the weight of social benefit is relatively high.

Generally speaking, the closeness degree of profitability of private cultural enterprises is higher than the closeness degree of social benefits, and the profitability of culture of private enterprises is relatively stronger than the social benefits, and the fluctuation range of the closeness degree of profitability is small. 
The closeness of profitability index shows a slight downward trend. In recent years, the economic benefits of private cultural enterprises continue to decline. The average closeness degree of social benefit evaluation index is below 0.3 , reflecting that there is still a lot of room for improvement of social benefit of private cultural enterprises. By analyzing the index of social benefit closeness, it is found that the level of social benefit has lowered the level of the evaluation index of the development dimension of private cultural enterprises, and the trend of the development index and the sub-index of social benefit is basically consistent. Social benefit is the key to improve the level of the development dimension of private cultural enterprises. Cultural enterprises have a special spiritual production attribute. On the basis of ensuring the stability and gradual improvement of economic profitability, enterprises should pay more attention to fulfill the responsibility of shareholders, employees and social responsibility, and give full play to the social radiation role of high-quality culture.

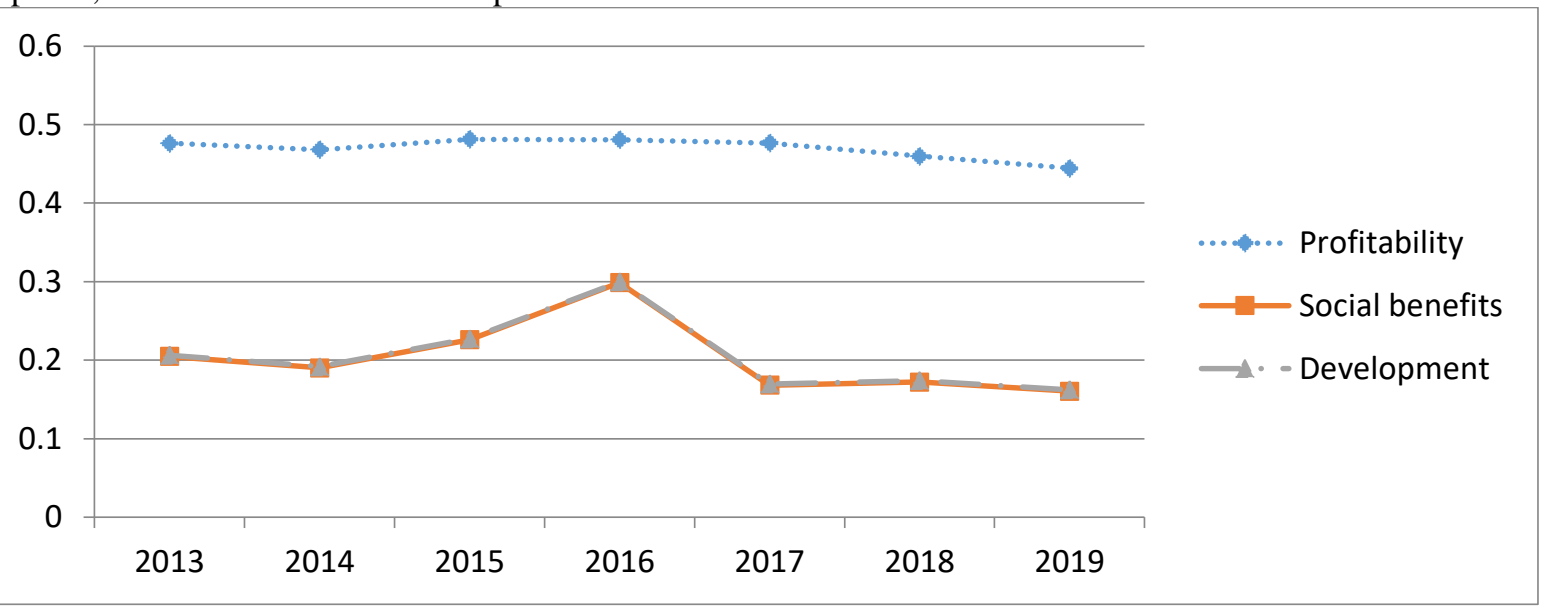

Figure 1 Evaluation results of development indicators

\subsubsection{Efficiency evaluation index}

The weight of efficiency evaluation index in the overall index is 0.0507 . From 2013 to 2019, the average closeness degree of efficiency index of private cultural enterprises was 0.1906, and the overall efficiency level was not very high, as shown in Figure 2.

By analyzing the three sub-indexes of efficiency dimension, it is found that the weights of operation efficiency, economic efficiency and operation capability are $0.0296,0.0006$ and 0.0206 respectively. The closeness degree of economic efficiency with a relatively low weight ratio is much higher than the index of operation efficiency and operation capacity. The average closeness degree of economic efficiency is 0.8605 , with a small fluctuation range and no obvious change trend. The closeness degree of operation efficiency and operation capacity index is similar to that of the efficiency index of private cultural enterprises. The closeness degree of both indexes is very low, with the average closeness degree being 0.2037 and 0.1450 respectively. The rising speed of operation efficiency is slightly faster than that of efficiency. As the total weight of operation efficiency and operation capacity is 0.0502 , the benefit level of private cultural enterprises is greatly reduced. Although the economic efficiency of private cultural enterprises is relatively high compared with the operation efficiency and operation capacity, the ratio of labor and capital investment is not very reasonable, the turnover speed of total assets is slow, and the utilization efficiency of assets is low. Under the constraints of the external market environment, private cultural enterprises should further adjust the proportion of input of internal human resources and means of production, improve the efficiency of input into output, and better achieve the financial goals of the enterprise. 


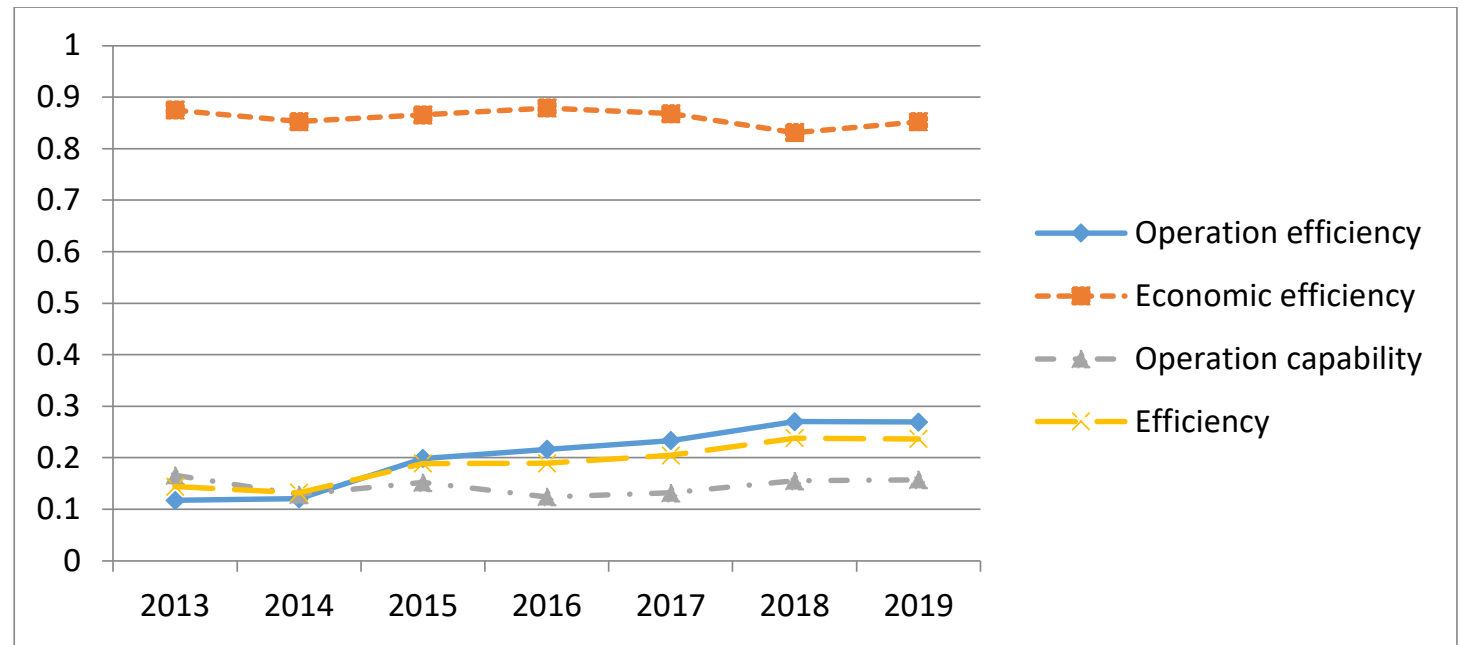

Figure 2 Efficiency index evaluation results

\subsubsection{Sustainability evaluation index}

Among the three sub-indexes of high-quality development of private cultural enterprises, the sustainable index has the largest weight proportion, accounting for 0.9040. Sustainable development has become a decisive indicator to measure whether private cultural enterprises can achieve high-quality development. The average closeness degree of sustainability index from 2013 to 2019 was 0.0888 , and the sustainability level of private cultural enterprises was relatively low, as shown in Figure 3.

The sub-indexes of sustainable development, technological competitiveness, enterprise growth and environmental friendliness accounted for 0.5794, 0.2077 and 0.1169 respectively. Technological competitiveness became the key factor for enterprises to achieve sustainable development. The average closeness degree of technical competitiveness index is 0.0565 , which is relatively low. From 2013 to 2019, r\&d investment intensity of private cultural enterprises continued to rise. The number of development patent grants and invention patent applications, which account for a large proportion, showed a slight downward trend, resulting in a slow growth of technological competitiveness. The average closeness degree of enterprise growth index is 0.0060 . In 2016, the asset growth rate of private cultural industry increased to 0.0289 , and then fell back to the original average level. Meanwhile, the closeness degree of environmental friendliness is also low. To achieve sustainable development, private cultural enterprises need to maintain innovation capital investment, absorb innovative talents, and increase the transformation and utilization rate of innovation achievements, so as to achieve direct and long-term economic growth.

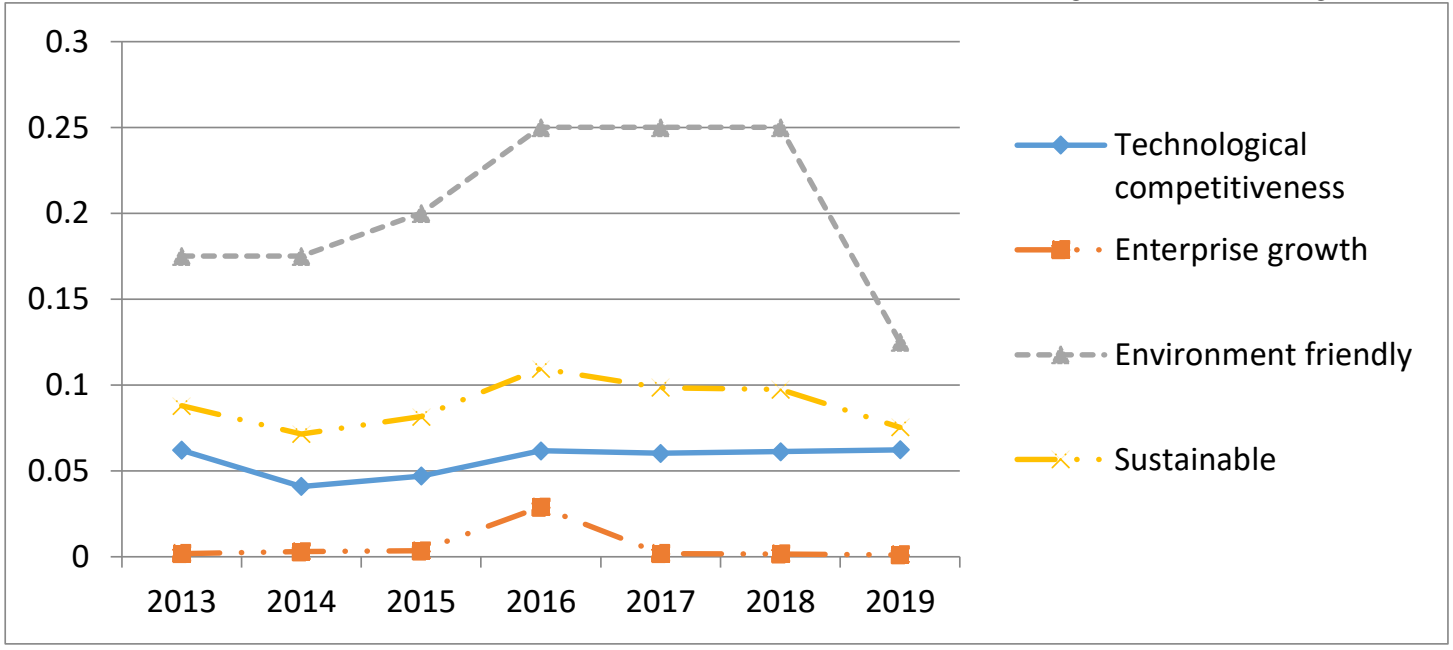

Figure 3 Evaluation results of sustainability indicators

\subsection{Results of \\ comprehensive evaluation of private cultural enterprises}

From 2013 to 2019, the average closeness degree of comprehensive evaluation index of high-quality development of private cultural enterprises was 0.0985 (the maximum value of closeness degree was 1), 
indicating that the enterprise development quality level was in a relatively low state. From 2013 to 2019, the efficiency index of private cultural enterprises showed a relatively stable growth in the fluctuation. The development index fluctuates the most, and the trend of sustainable index is basically consistent with the comprehensive evaluation index of high quality development of private cultural enterprises. Among the three sub-indexes, the weight of the sustainable evaluation index is as high as $90.40 \%$, but the closeness degree is at the lowest level among the three indexes, which greatly reduces the high quality development level of private cultural enterprises. To pursue high-quality development, private cultural enterprises should first solve the key problem of sustainable development of enterprises, and then deal with the balance of enterprise development, efficiency and sustainability.

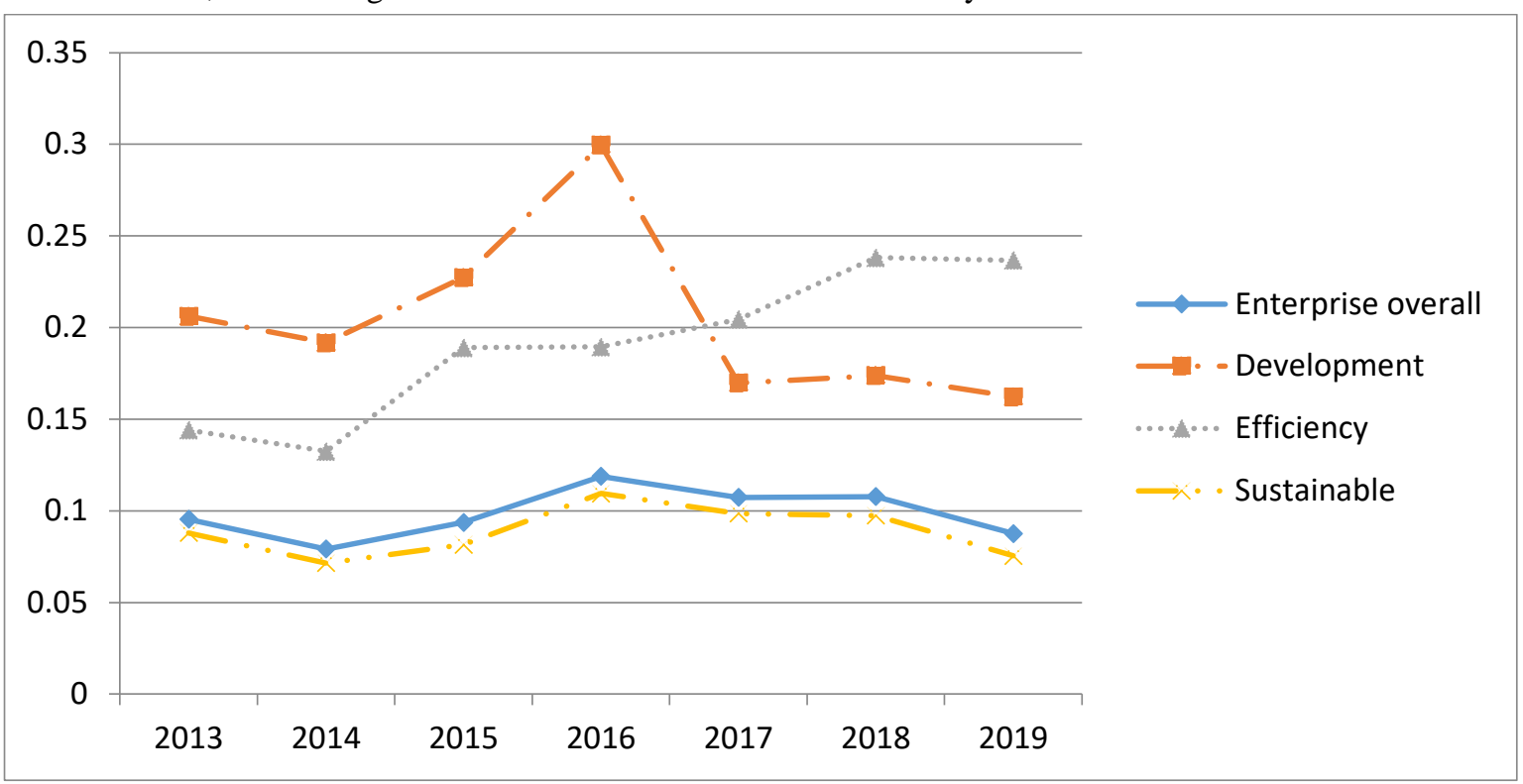

Figure 4 Results of comprehensive index evaluation of private cultural enterprises

\section{CONCLUSIONS AND RECOMMENDATIONS}

The empirical results show that the overall development quality level of private cultural enterprises in China is low. The social benefit is obviously lower than the economic benefit, and the operating efficiency and operating ability are at a low level. The realization of economic profits of private cultural enterprises consumes a lot of social resources, and there is much room for improvement in the allocation efficiency. Sustainable management of private cultural enterprises is the decisive factor to realize high-quality development. In order to improve the high-quality development level of private cultural enterprises, from the enterprise level, entrepreneurs and senior management teams of private cultural enterprises need to have a high sense of social responsibility and improve the social benefits of private cultural enterprises. Higher social benefits are conducive to the establishment of corporate brand, and high-quality brand will further promote the improvement of economic benefits of enterprises. Private cultural enterprises need to incorporate technological innovation into their development plans, increase the investment in $R \& D$, build a technical R\&D teams, improve the treatment and happiness of r\&d and innovation talents, and focus on high-quality projects to grow. From the policy point of view, the government can through preferential fiscal, taxation, land means or support state-owned and private cultural enterprises cooperation projects to guide the development direction of private cultural enterprises, secondly to strengthen intellectual property rights legislation, protect the technological innovation patents, and promote the high-quality development of private cultural enterprises.

\section{ACKNOWLEDGMENTS}

This work was supported by Postgraduate Innovation Fund Project of Jiangxi Provincial Department of Education: Construction and Evaluation of High Quality Development Index System of Private Cultural Service Enterprises (YC2020-S146).

\section{REFERENCES}

[1] Dai Xinling. Promote the high-quality development of the private economy [J]. People's Forum, 2020(15): 168-169.

[2] Xie Di and Li Ziqi. Several cognitive Issues on the Development of Private Economy $[\mathrm{J}]$. Red flag manuscript, 2018(22): 19-21. 
[3] Du Xianghong and Zhou Yongmei. Research on the Influencing Factors of the High-quality Development of Private Economy [J]. Accounting Communications, 2020(17): 98-101.

[4] Li Yining. China's roads and high-quality development of private enterprises [J]. Macro Quality Research, 2020, 8(02): 1-8.

[5] Tian Qiusheng. The theoretical connotation and practical requirements of high-quality development [J]. Journal of Shandong University (Philosophy and Social Sciences Edition), 2018(06): 1-8.

[6] Lv Wei. Explore an evaluation index system that reflects high-quality development [J]. Chinese People's Congress, 2018(11): 23-24. 